\title{
Erratum to: The interaction of corporate dividend policy and capital structure decisions under differential tax regimes
}

\author{
Ufuk Ince • James E. Owers
}

Published online: 20 January 2012

(C) Springer Science+Business Media, LLC 2012

\section{Erratum to: J Econ Finan \\ DOI 10.1007/s12197-009-9101-7}

The authors of the above paper would like to correct the current affiliation for Ufuk Ince. His correct affiliation is given below.

The online version of the original article can be found at http://dx.doi.org/10.1007/s12197-009-9101-7.

U. Ince $(\triangle)$

School of Business, Pacific Lutheran University, Tacoma, WA 98447, USA

e-mail: inceua@plu.edu

J. E. Owers

Robinson College of Business, Georgia State University, Atlanta, GA 30303, USA

e-mail: jowers@gsu.edu 